\title{
Factors associated with the care of elderly persons with Primary Health Care sensitive conditions
}

\author{
Anderson da Silva Rêgo' \\ Leidyani Karina Rissardo ${ }^{7}$ \\ Giovana Aparecida de Souza Scolari ${ }^{1}$ \\ Rafaely de Cássia Nogueira Sanches' \\ Lígia Carreiral \\ Cremilde Aparecida Trindade Radovanovic ${ }^{3}$
}

Abstract

Objective: to analyze factors associated with the care of the elderly for Primary Health Care sensitive conditions in an Emergency Care Unit. Method: a cross-sectional study was carried out in a municipal district located in the northwest of the state of Paraná, Brazil, between May and November of 2015. A semi-structured instrument was used, consisting of three distinct blocks that addressed sociodemographic profile, characterization of care and the reasons that led the elderly to seek care in the unit. The data were submitted to descriptive analysis and logistic regression for the treatment of variables. Results: A total of 191 elderly persons, who were female (56\%), had less than eight years of schooling $(85.3 \%)$ and were retirees $(78.5 \%)$ were interviewed. The results showed that people with chronic morbidities were 1.42 times more likely (CI: 1.08 - 5.42) to seek the Emergency Care Unit prior to the Basic Health Unit and were 1.65 times more likely (IC: $1.01-6.82$ ) to be referred by the unit for care. The lack of a doctor in Basic Health Units was also a factor responsible for the 1.36 times greater chance (CI: 1.03 - 5.38) of the elderly being referred to the Emergency Care Unit for primary care sensitive conditions. Conclusion: the lack of human resources in the first level of care of the health service, together with the need for treatment of morbidities, were factors associated with the elderly seeking treatment for primary care sensitive conditions, with diseases of the osteomuscular and connective tissue systems the main reasons for seeking such care (47.6\%).
Keywords: Elderly. Emergency Medical Services. Primary Health Care. Geriatric Nursing.

Universidade Estadual de Maringá (UEM), Departamento de Enfermagem, Programa de Pós-Graduação em Enfermagem. Maringá, PR, Brasil.

Correspondence

Anderson da Silva Rêgo

E-mail: Anderson.dsre@hotmail.com 


\section{INTRODUCTION}

The increase in life expectancy and the aging of the population have occurred in an accelerated manner in developing countries. In Brazil this phenomenon has been associated with an increase in the incidence and prevalence of chronic noncommunicable diseases, with $79 \%$ of Brazilians over 60 years of age reporting chronic health conditions ${ }^{1-3}$. The average burden of illness in years of life lost, adjusted for disability, is made up of infectious diseases (14.8\%), external causes $(10.2 \%)$ and chronic diseases $(66.2 \%)$, constituting a triple disease burden ${ }^{4}$.

To meet the impact of the health needs of the elderly, the Ministry of Health created the National Health Policy for the Elderly in 2006. This is aimed at the promotion, prevention and recovery of health, based on the guidelines of the Sistema Único de Saúde (the Unified Health System) (SUS), seeking to develop individual and collective resolutive actions offered under Primary Health Care (PHC). Such actions should be carried out by the Family Health Strategy (FHS) in Basic Health Unit (BHU) coverage areas, supported by and linked to secondary and tertiary care for medium and high complexity referrals ${ }^{5,6}$.

The Brazilian health system has adopted PHC as the preferred entry point for users into health services. However, this care point includes challenges that must be overcome, such as the insufficient provision of health services due to a lack of human and technological resources ${ }^{7}$. This fact subsequently affects demand in other health care facilities, such as Emergency Care Units (ECUs).

The ECUs offer an intermediate level of care, mediating referrals from the BHUs/FHS and hospitals to resolve acute or exacerbated clinical cases. A study carried out in southern Brazil revealed that most of the treatment provided by this high complexity service is not an ideal fit for urgent and emergency cases, creating confusion in the organizational structure, with emotional harm to patients and professionals, compromising the quality of care provided ${ }^{8}$. Treatment of PHC-sensitive conditions in ECUs is an evaluative indicator of the first level of health care, as efficient actions in the promotion and prevention of comorbidities result in a reduction in hospital admissions?.
Hospitalizations for Conditions Sensitive to Primary Care (HCSPCs) is a list developed by the Ministry of Health, published under Ordinance 221/2008, which indicates hospitalizations that would be avoidable if basic care services were effective and/or accessible? ${ }^{9}$ HCSPCs can include, in certain conditions, non-controlled complications of a chronic illness or other conditions related to actions and services of prevention ${ }^{10}$.

Understanding the sensitive causes of the care provided in the ECUs allows the identification of the effects of PHC strategies, guiding the planning of interventions in such location, contributing greatly to the reduction of avoidable care, especially among the elderly population ${ }^{11}$. In view of the above, the objective of this study was to analyze the factors associated with the care of the elderly in ECUs for conditions sensitive to primary health care.

\section{METHOD}

A cross-sectional study was carried out between May and November 2015 in a municipal region located in the northwestern part of the state of Paraná, Brazil. The municipal region in question has an estimated population of 403,063 inhabitants, with 35 BHUs and 74 FHS teams, providing population coverage of $68.01 \%{ }^{12}$. It has two functioning ECUs. The study was carried out in one of these units, which covers around 200,000 people and is registered with $11 \mathrm{BHUs}$ in the municipal region ${ }^{13}$.

To calculate the sample, the number of elderly persons receiving care in the ECU in the four months prior to the beginning of data collection was surveyed, resulting in an average of 300 elderly individuals treated per month. A proportional stratified sample was performed, considering an estimate of error of $5 \%$ and a $95 \%$ confidence interval, plus $10 \%$ for possible losses. The final sample was 191 people. The selection technique was non-probabilistic based on traffic, or in other words, the elderly persons who attended the ECU were invited to participate in the study. Inclusion depended on the verification of adequate cognitive ability through the application of the Mini Mental State Exam (MMSE), with cognitive decline considered a score equal to or less than 24 points ${ }^{14}$. 
In addition to assessing the cognitive status, the following inclusion criteria were adopted: people of both genders, aged 60 or over, who were not classified within the emergency criteria (green and blue color) of the risk classification of the Manchester Screening Protocol, which consists of classifying the patient according to their clinical condition, rather than order of arrival ${ }^{15}$.

After the classification of risk, the medical consultation and the confirmation that the treatment provided was primary care sensitive, the elderly were approached to verify if the diagnosis received was classified by the Tenth Revision of the International Classification of Diseases (ICD-10) and was included on the Brazilian HCSPC List, which has 19 diagnostic groups?

Next, a semi-structured instrument was applied, divided into three distinct blocks. A pilot test was first carried out, which was submitted to modifications for qualification and adaptation to the context in which it was applied.

The first block of the instrument obtained information regarding the patient's identification and socio-demographic situation (gender; age; schooling; economic situation; referral BHU) and clinical data (existing morbidities; recurring visits to ECU; health plan). The second block dealt with the characterization of the care provided in the unit (risk classification; if referred by BHU and, if so, which professional carried out the referral; interviewee's perception about the need for referral, when referred; the health need described by the patient; and the diagnosis given, which would indicate the inclusion of the subject in the study, according to the ICD-10 and HCSPC).

The third block dealt with the reasons that led to seeking ECU care (frequency of seeking care in the $\mathrm{BHU}$; if care was sought for a health complaint in the $\mathrm{BHU}$ before the ECU; reasons for not seeking care in the BHU; if care was sought in the BHU, what led to the non-resolution of the health complaint; how the individual evaluated the service in the BHU and in case of an unsatisfactory evaluation, what was the reason; opinions on what should be improved in the BHU; classification of the severity of the current health problem; if treatment was provided for the existing morbidity in the BHU; knowledge about the role of the BHU and ECU in providing care; expectation of care at the ECU).

The following dependent variables were adopted: Referred by $B H U$, through a BHU referral form confirming that care was sought in the BHU and for some reason the individual was referred; and Sought Care in BHU before ECU, where the participant was questioned about seeking care at the BHU before going to the ECU. The two dependent variables were evaluated from the responses of the interviewees and the absence of referral by the BHU for the majority of those who said they had sought the unit to treat their health problem.

The independent variables were divided into two blocks. The first evaluated the reasons why the individual did not seek treatment at the BHU: evaluation of the service performed by the BHU; presence of chronic morbidity, such as those requiring follow-up care; geographic location, with a walking distance of twenty to thirty minutes considered as a parameter, taking into account factors related to public transportation, such as cost and waiting time ${ }^{16}$; lack of doctors; lack of confidence in BHU care; BHU service hours.

The second group evaluated the reasons that led to seeking care at the ECU: better technological and treatment resources of the ECU, such as the presence of available doctors for treatment and equipment for imaging tests; better service; the fact that appointments are not needed at the ECU; where individuals considered their clinical situation as an ECU case, after which they were questioned about their perception of their current state of health; fast service; possibility of examinations without the need to schedule a date and time, unlike the BHU; same day delivery of test results, again unlike the BHU, where the wait was approximately 10 days..

All questionnaires were checked by the researchers for correction of possible typing errors and failures regarding the requirements considered for inclusion of the subject in the study.

A descriptive analysis of the sociodemographic data was performed in percentage and absolute numbers. The association between independent 
and dependent variables was verified using univariate logistic regression analysis using the Forward method, considering and inserted in ascending order those that remained in the model as they presented a value of $\mathrm{p}<0.20$ and multivariate. The magnitude of the associations was estimated by Odds Ratio (OR), adopting the $95 \%$ interval as a measure of precision, considering the statistical significance of those with a value of $p<0.05$.

The study was developed in accordance with the ethical precepts recommended by Resolution $466 / 2012$ of the National Health Council ${ }^{17}$ and its design was approved by the Standing Committee on Ethics in Research with Human Beings (Approval no. 137/2014). All the participants signed two copies of a Free and Informed Consent Term (FICF).

\section{RESULTS}

A total of 191 elderly people were interviewed, the majority of whom were aged between 60 and 70 years $(49.7 \%)$, female $(56 \%)$ and lived with a partner (59.1\%). A large part of the sample had $<8$ years of schooling $(85.3 \%)$ and were retirees and/ or pensioners $(78.5 \%)$. In terms of their clinical situation, the majority reported a chronic morbidity undergoing treatment (91.1\%) and did not have a supplementary healthcare insurance plan (70.7\%).

Regarding ICD-10 and HCSPC classification, most visits were due to diseases of the musculoskeletal system and connective tissue (47.6\%), respiratory system illnesses $(30.3 \%)$ and diseases of the digestive tract $(10.9 \%)$, shown in Table 2.

Table 1. Sociodemographic characteristics of elderly persons receiving care at ECU. Paraná, 2015.

\begin{tabular}{lll}
\hline Variables & $\mathrm{n}$ & $\%$ \\
\hline Age (years) & 95 & 49.7 \\
60 to 70 & 50 & 26.2 \\
71 to 80 & 46 & 24.1 \\
$>81$ & & 56.0 \\
\hline Gender & 107 & 44.0 \\
Female & 84 & 59.1 \\
Male & & 40.9 \\
Marital Status & 113 & \\
With Partner & 78 & 85.3 \\
Without Partner & & 14.7 \\
\hline Schooling (years) & 163 & \\
$<8$ & 28 & 70.7 \\
$>8$ & & 15.7 \\
\hline Economic situation & 150 & 5.8 \\
Retired & 30 & \\
Employed & 11 & \\
Unemployed & & \\
\hline Health Plan & 56 & \\
Yes & 135 & \\
No & & \\
\hline
\end{tabular}


Table 2. Characterization of care requirements of elderly persons classified with complaints sensitive to primary care who sought treatment at the ECU. Paraná, 2015.

\begin{tabular}{llll}
\hline Main complaint* & CID-10** & N & $\%$ \\
\hline Osteomuscular and connective tissue diseases & M00-M99 & 91 & 47.6 \\
Diseases of the respiratory tract & J00-J99 & 58 & 30.3 \\
Diseases of the circulatory system & I00-I99 & 13 & 6.8 \\
Diseases of the genitourinary system & N00-N99 & 06 & 3.1 \\
Diseases of the digestive system & K00-K93 & 21 & 10.9 \\
Diseases of the nervous system & G00-G99 & 17 & 8.9 \\
Symptoms, signs, and abnormal findings from clinical and & R00-R99 & 08 & 4.1 \\
laboratory tests, not classified elsewhere & & & \\
\hline
\end{tabular}

*Some elderly persons had more than one complaint; **ICD: International Classification of Diseases

In univariate analysis, association with the variable sought $\mathrm{BHU}$ before the ECU found that elderly persons with chronic morbidity were 1.67 times more likely not to seek the BHU before the ECU. It was also found that the lack of doctors $(p=0.038)$ and lack of confidence in care $(p=0.025)$, reduced the chance of seeking the BHU for a consultation. The improved resources available $(p=0.038)$ and the fact that it is not necessary to schedule an appointment in the ECU $(p=0.002)$ also reduced the chance of seeking the BHU for consultation (Table 3).
The variable relating to elderly persons who were proven to have been referred by the BHU found that those with a chronic morbidity were 2.75 times more likely to be referred for care in the ECU, and that the lack of a physician resulted in a 2.81 greater chance of being referred for care in this unit (Table 3).

The results of multivariate analysis found that those with chronic morbidities were 1.42 times more likely to seek the ECU before the BHU and 1.65 times more likely to be referred to the ECU by the BHU. The lack of a doctor resulted in a 1.36 times greater chance of the elderly being referred to the ECU to meet their health needs (Table 4). 


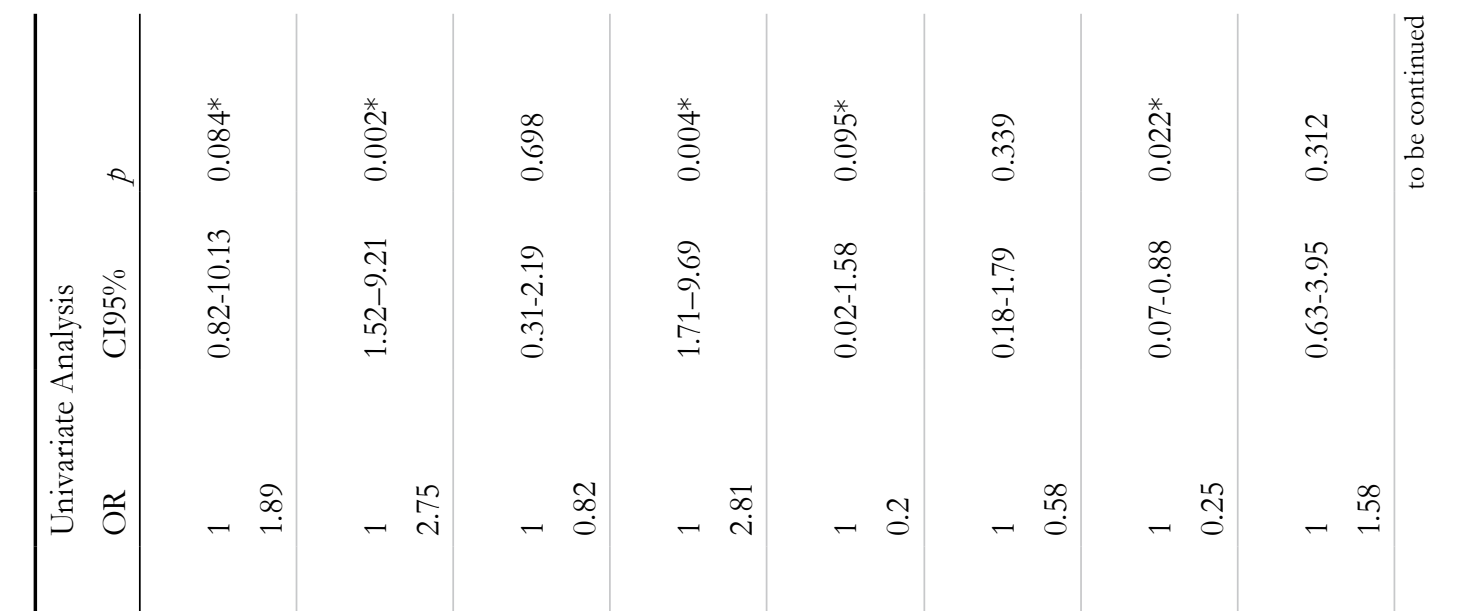

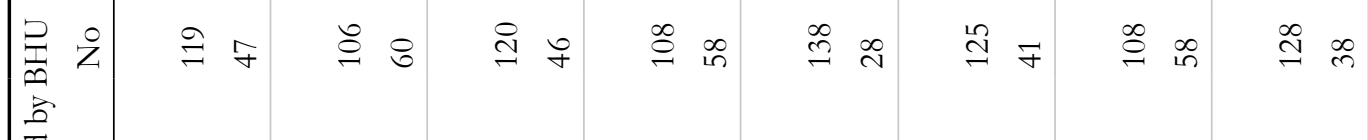
离

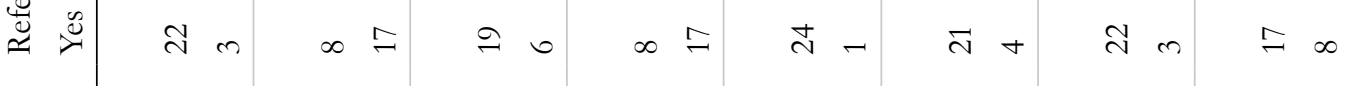

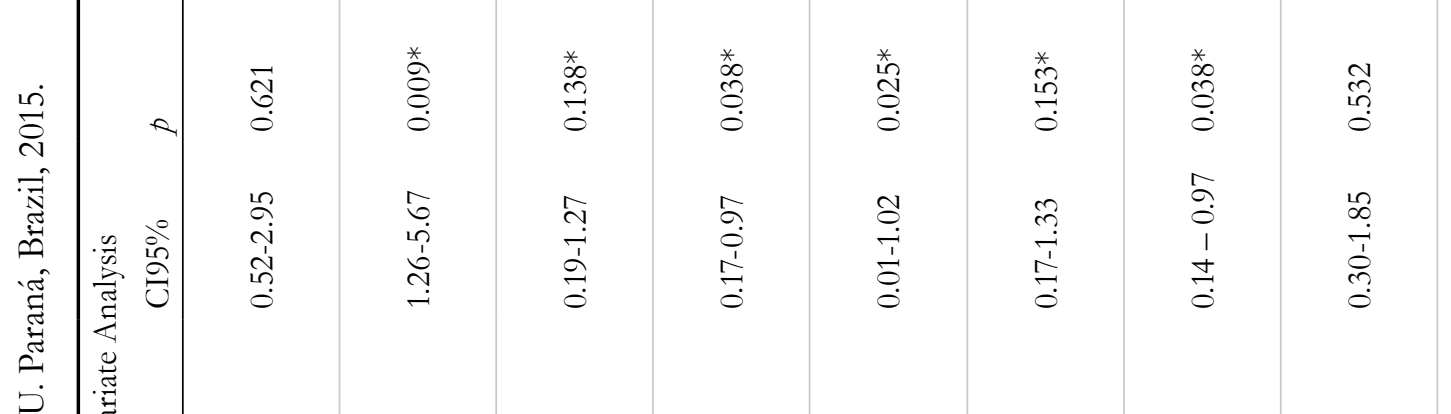

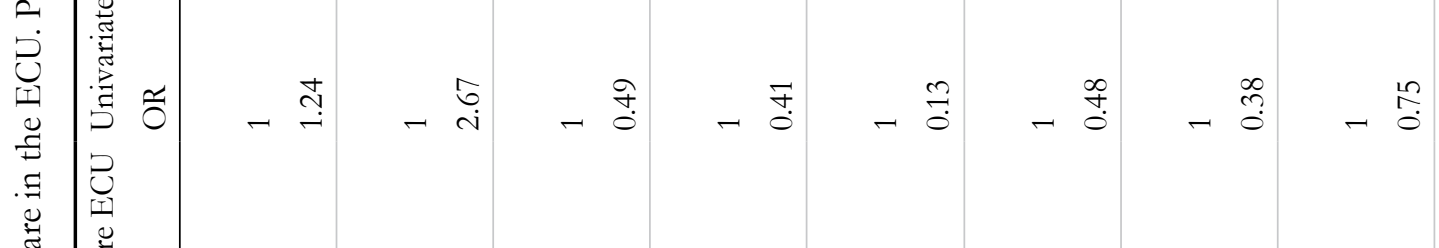

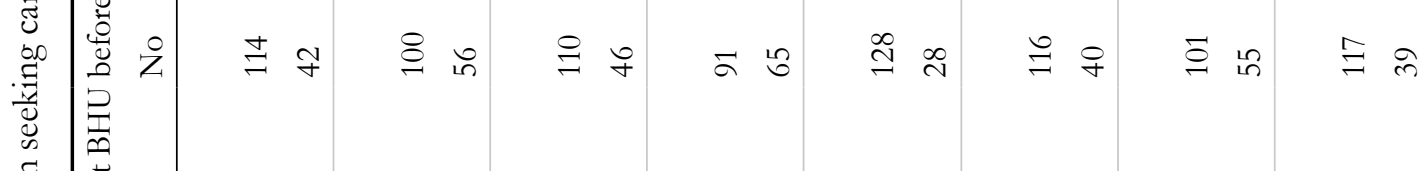

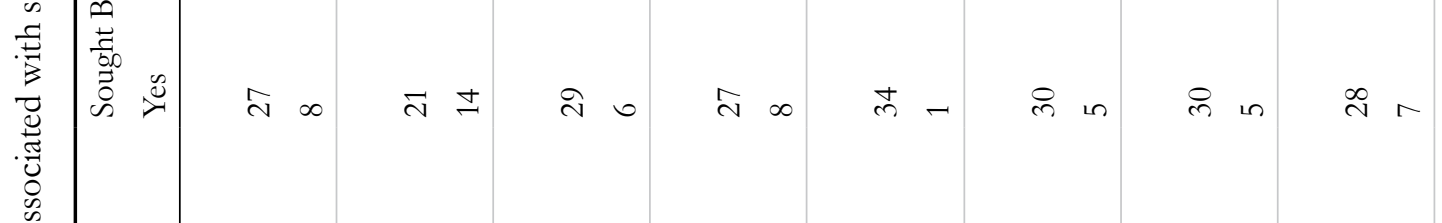




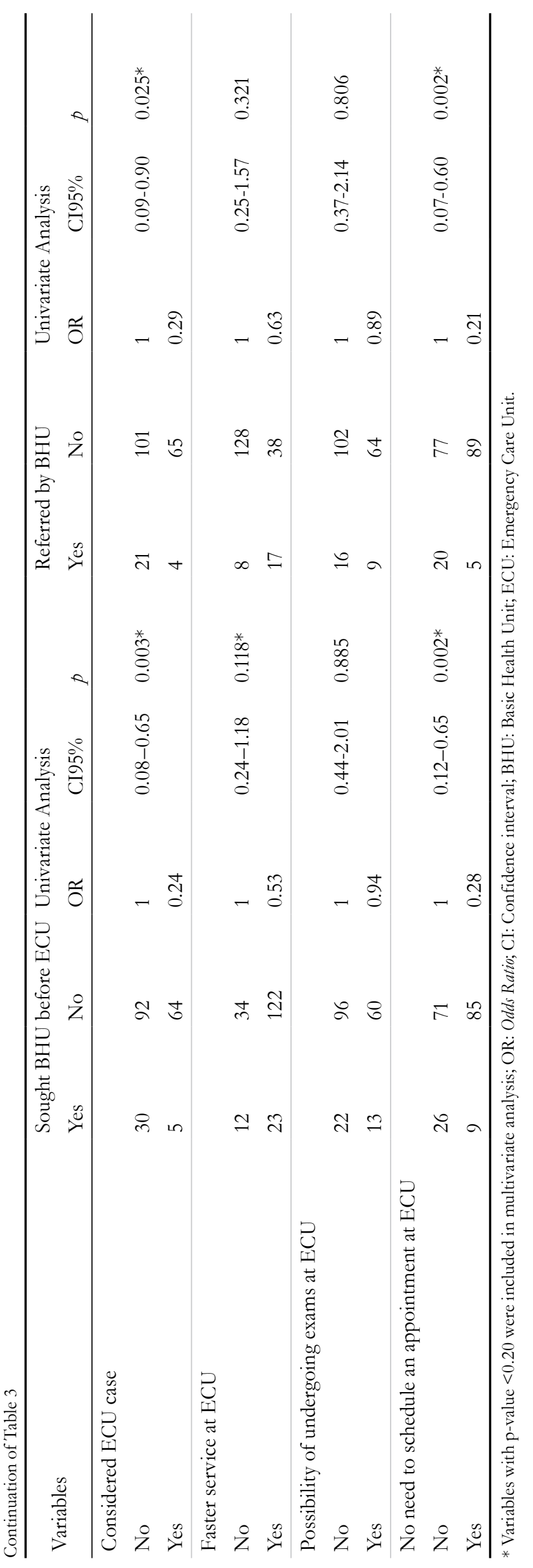


Table 4. Multivariate analysis of factors associated with elderly persons seeking care at the ECU. Paraná, Brazil, 2015.

\begin{tabular}{|c|c|c|c|c|c|}
\hline \multirow[t]{2}{*}{ Variables } & \multicolumn{2}{|c|}{$\begin{array}{l}\text { Sought care at BHU } \\
\text { before ECU }\end{array}$} & \multicolumn{2}{|c|}{ Multivariate Analysis } & \multirow[b]{2}{*}{$p$} \\
\hline & Yes & No & OR & $\mathrm{CI} 95 \%$ & \\
\hline \multicolumn{6}{|c|}{ Presence of Morbidities } \\
\hline No & 14 & 100 & 1 & $1.08-5.42$ & 0.032 \\
\hline Yes & 21 & 56 & 1.42 & & \\
\hline \multicolumn{6}{|c|}{ Lack of Doctors at BHU } \\
\hline No & 27 & 91 & 1 & $0.15-0.96$ & 0.041 \\
\hline Yes & 8 & 65 & 0.38 & & \\
\hline \multicolumn{6}{|c|}{ Considered ECU Case } \\
\hline No & 30 & 92 & 1 & $0.07-0.59$ & 0.003 \\
\hline Yes & 5 & 64 & 0.20 & & \\
\hline \multicolumn{6}{|c|}{ No need to schedule an appointment at ECU } \\
\hline No & 26 & 71 & 1 & $0.12-0.72$ & 0.007 \\
\hline \multirow[t]{2}{*}{ Yes } & 9 & 85 & 0.31 & & \\
\hline & \multicolumn{2}{|c|}{ Referred by BHU } & \multicolumn{2}{|c|}{ Multivariate Analysis } & \\
\hline Variables & Yes & No & OR & $\mathrm{CI} 95 \%$ & $p$ \\
\hline \multicolumn{6}{|c|}{ Presence of Morbidities } \\
\hline No & 8 & 106 & 1 & $1.01-6.82$ & 0.043 \\
\hline Yes & 17 & 60 & 1.65 & & \\
\hline \multicolumn{6}{|c|}{ Lack of Doctors at BHU } \\
\hline No & 8 & 108 & 1 & $1.03-5.38$ & 0.032 \\
\hline Yes & 17 & 58 & 1.36 & & \\
\hline
\end{tabular}

OR: Odds Ratio; CI: Confidence Interval; BHU: Basic Health Unit; ECU: Emergency Care Unit.

\section{DISCUSSION}

The FHS has been expanding in recent years. Data show that in 1998, the country had 2,195 teams registered with the Ministry of Health, covering $4.4 \%$ of the Brazilian population. At the beginning of 2016 this number had grown to 48,410 teams, with a population coverage of approximately $64 \%$. In the state of Paraná, the numbers show an even more significant increase, with the number of teams increasing from 115 in 1998 to 2,868 in 2016, covering $68 \%$ of the population of the state ${ }^{18}$.

In the municipal region where the study was carried out, the data also showed an increase in the number of registered teams, with 75 currently in operation, providing population coverage of $68.01 \%{ }^{15,18}$. Despite this progress, there are still complex challenges in PHC to be overcome, such as using the information that is collected and provided by the FHS teams themselves. This disarticulation in the PHC micro-policy reflects on the health care provided, which, in many situations, is non-resolutive, causing the population to seek other levels of care to meet their health needs?

The use of the HCSPC indicator allows the identification of the treatment provided and makes it possible to classify such treatment according to the diagnosis received. It relates the characteristics of the care provided to the attributes of PHC in preventing, diagnosing and treating diseases, as well as the monitoring and control of the health of people with chronic diseases. These actions, when effective, reduce the frequency of PHC-sensitive consultations at other levels of complexity ${ }^{19}$.

The study was aimed at the elderly population, as hospitalization expenses are higher in this age group due to their physiological, economic and social 
vulnerability ${ }^{20}$. The number of elderly women was slightly higher than the number of men, which is in line with studies on the profile of the population treated by health services ${ }^{19,21}$. The majority did not have more than eight years of schooling which puts them in a situation of social vulnerability. A study has demonstrated that low educational levels lead to lower rates of adherence to the treatment of chronic diseases, strongly influenced by the difficulties of access to health services ${ }^{20}$.

Elderly people who live with partners behave differently than those who live alone. This is due to the support between the couple, strengthening them against the aging process, which is often combined with chronic diseases. The leading role of women in the family group, resulting in greater control of the seeking of health care for their partners, is also relevant. This fact indicates the need to consider the differences of genres and family compositions to ensure a quality of health care that is more coherent with the unique needs of the users ${ }^{22}$.

It is important to emphasize the fundamental importance of modifying the approach of health professionals who treat the elderly population in PHC through continuous education and professional valorization, with a strengthening of the connection with and understanding of health needs. The present study showed that the elderly who sought the BHU before the ECU and who were undergoing treatment of a chronic morbidity were twice as likely to be referred to the ECU by a health professional. The same result was observed for the variable that investigated if the elderly were referred by a BHU professional due to the lack of doctors in the BHU.

PHC is considered to be the first contact with the health service and should be understood as the preferred entry point for the use of health actions and services. The health care provided at this level should consider the characteristics of the population, the behavior of the individual, and the technological resources available $e^{23,24}$.

Disconnected actions result in gaps in care for health service users, especially the elderly. The results of the present study were similar to the results of a study carried out with BHU users, health professionals and managers to evaluate the integrality of actions, which also revealed user dissatisfaction with the non-resolution of acute complaints, which can therefore be considered another reason for seeking care in UPA ${ }^{23,24}$.

The result indicated by the variable that investigates whether the elderly sought treatment at the BHU before the ECU reveals that elderly persons with chronic morbidities are more likely to seek the ECU first. Other studies have identified that many users seek the ECU because of the lack of medical professionals at the $\mathrm{UBS}^{23,24}$. Other factors include the guarantee of care by doctors and the availability of complementary exams, without the necessity of prior appointments, offered by the UPA ${ }^{25}$.

The fact that the ECU offers uninterrupted medical care represents a major challenge for public health, as the behavior of the population and the health professionals themselves is still influenced by the biomedical model of hegemony, with the concept of prevention little debated and/or understood by society. This situation reflects a need for health professionals to learn the importance of the articulation between levels of health services and actions, according to the guidelines of the Health Care Networks that indicate PHC as a model of $\operatorname{care}^{26,27}$.

The pyramid structure of the health system, adopted since the beginning of the $20^{\text {th }}$ century, with the flow of users at various levels of technological complexity, has not provided satisfactory results for the needs of the population. This model of care is not consistent with the health needs of the population, especially considering population aging and the prevalence of chronic diseases. The care coverage provided does not integrate with care actions, which have proven to be insufficient for the reality of Brazil. ${ }^{28}$ The inadequacy of ECU demand has been described both by national ${ }^{28,29}$ and international researchers ${ }^{30,31}$. This result suggests that many units of medium complexity address situations that should be accommodated, solved and accompanied by basic care $e^{28,32}$.

The current structure of the SUS suggests it is more prepared to deal with acute than chronic conditions. This phenomenon has also been experienced in other parts of the world. A study carried out in Australia revealed that conditions sensitive to primary care were more prevalent in the 
over- 60 population, and that the majority of visits dealt with complications of chronic and degenerative diseases ${ }^{30}$. The results of this study indicated diseases of the musculoskeletal system and connective tissue and those of the respiratory and circulatory system as the main reasons for seeking care in ECU.

Also corroborating the results of the present study, a literature review study pointed out that doctor availability and the continuity of primary care can reduce hospitalization for acute problems arising from chronic morbidities, such as arterial hypertension and diabetes Mellitus ${ }^{31}$. This finding reinforces the need for longitudinal care for those with chronic morbidities, in order to avoid possible complications, thus avoiding re-hospitalizations

One limitation of the present study was the size of the sample and the fact that it was performed in only one of the two UPAs located in the municipal region, which makes it impossible to generalize the results, which are therefore limited only to the population in question. In addition, another limitation was that the research was carried out within the unit, which may result in constraint and consequently allow the environment to influence the participants' responses. It is reiterated that the study indicates factors that led to treatment and not hospitalizations due to

\section{REFERENCES}

1. Evangelista RA, Bueno AA, Castro PA, Nascimento JN, Araújo NT, Aires GP. Perceptions and experiences of elderly residents in asylum. Rev Esc Enferm USP [Internet]. 2014; [acesso em 07 mar. 2016];48(Esp 2):85-91. Disponível em: http://www. journals.usp.br/reeusp/article/view/103111/101443

2. Costa GD, Souza RA, Yamashita CH, Pinheiro JCF, Alvarenga MRM, Oliveira MAC. Evaluation of professional knowledge and attitudes on dementia patient care: a trans-cultural adaptation of an evaluation instrument. Rev Esc Enferm USP [Internet] 2015 [acesso em 01 fev. 2016];49(2):298-308. Disponível em: http://www.scielo.br/scielo.php?script=sci_ arttext\&pid=S0080-62342015000200298\&lng=en conditions sensitive to primary care, which may assist the understanding of professionals regarding the demand for services more suited to another level of care.

\section{CONCLUSION}

The results of this study allow us to conclude that elderly persons with chronic diseases are more likely to seek BHUs and to be referred by primary care professionals. It was also found that the lack of doctors in the $\mathrm{BHU}$ is a factor that leads to an increase in the demand for treatment for primary care sensitive conditions.

There are therefore barriers between the health needs of the elderly and the provision of services, which shows that the reorganization of primary health care will not be sufficient to solve the health problems of the population, and that other means of organizing the flow of treatment are required. There is an urgent need for administrative policies that implement strategies to minimize ECU care for conditions sensitive to primary care, especially for the elderly population, which has specific characteristics and needs continuous and comprehensive care, both of which are found in primary care.
3. Mendes EV. O acesso à atenção primária à saúde. Brasília, DF: CONASS; 2016.

4. Mendes EV. A construção social da atenção primária à saúde. Brasília, DF: Conselho Nacional de Secretários de Saúde; 2015.

5. Brasil. Ministério da Saúde, Secretaria de Atenção À Saúde, Departamento de Atenção Básica. Política Nacional de Atenção Básica. 4. ed. Brasília, DF: Ministério da Saúde; 2007.

6. Almeida RT, Ciosak SI. Communication between the elderly person and the Family Health Team: is there integrality? Rev Latinoam Enferm [Internet]. 2013 [acesso em 01 fev. 2016];21(4):884-90. Disponível em: http://www.scielo.br/scielo.php?script=sci_ arttext\&pid=S0104-11692013000400884\&lng=en 
7. Oliveira AMS, Menezes TMO. A enfermeira no cuidado ao idoso na estratégia saúde da família: sentidos do vivido. Rev Enferm UERJ [Internet]. 2014 [acesso em 03 mar. 2016];22(4):513-8. Disponível em: http://www.e-publicacoes.uerj.br/index.php/ enfermagemuerj/article/view/15373/11629

8. Oliveira SN, Ramos BJ, Piazza M, Prado ML, Reibnitz KS, Souza AC. Emergency care units (UPA) 24h: the nurses' perception. Texto \& Contexto Enferm [Internet]. 2015 [acesso em 11 mar 2016];24(1):238-44. Disponível em: http://www. scielo.br/scielo.php?script $=$ sci_arttext\&pid $=$ S010407072015000100238\&lng=en

9. Brasil. Portaria n. ${ }^{\circ}$ 221, de 17 de abril de 2008. Publica a lista brasileira de internações por condições sensíveis à atenção primária. Diário Oficial da União. 221(I):70-1;18 abr. 2008.

10. Pereira FJR, Silva CC, Lima Neto EA. Condições Sensíveis à Atenção Primária: uma revisão descritiva dos resultados da produção acadêmica brasileira. Saúde Debate [Internet]. 2014 [acesso em 05 mar. 2016];38(Esp):331-42. Disponível em: http://www. scielo.br/scielo.php?script $=$ sci_arttext\&pid $=$ S010311042014000600331\&lng=en

11. Marques AP, Montilla DER, Almeida WS, Andrade CLT. Hospitalization of older adults due to ambulatory care sensitive conditions. Rev Saúde Pública. 2014;48(5):817-26.

12. Instituto Paranaense de Desenvolvimento Econômico e Social. Caderno Estatístico do Município de Maringá. Curitiba: [sem editor]; 2016.

13. Rissardo LJ, Rego AS, Scolari GAS, Radovanovic CAT, Decesaro MN, Carreira L. Elderly care unit ready for sensitive conditions to primary health care. REME Rev Min Enferm. 2016;20:1-7.

14. Melo DM, Barbosa AJG. Use of the Mini-Mental State Examination in research on the elderly in Brazil: a systematic review. Ciênc Saúde Coletiva. 2015;20(12):3865-76.

15. Souza CC, Araújo FA, Chianca TCM. Scientific Literature on the Reliability and Validity of the Manchester Triage System (MTS) Protocol: a Integrative Literature Review. Rev Esc Enferm USP. 2015 [acesso em 01 fev. 2016];49(1):144-51. Disponível em: http://www.scielo.br/scielo.php?script=sci_ arttext\&pid=S0080-62342015000100144\&lng=en

16. Muraro CF, Gigante LP, Nedel FB, Carvalho THML, Domenech SC, Gevaerd MS. Estratégia saúde da família e as internações por condições sensíveis a atenção primária nos idosos. Rev baiana Saúde Pública. 2013;37(1):20-33.
17. Brasil. Resolução n 466, de 12 de dezembro de 2012. Aprova normas regulamentadoras de pesquisas envolvendo seres humanos. Diário Oficial da União; 2013.

18. Melo MD, Egry EY. Social determinants of hospitalizations for ambulatory care sensitive conditions in Guarulhos, São Paulo. Rev Esc Enferm USP. 2014;48(Esp.):129-36.

19. Rehem TCMSB, Ciosak SI, Egry EY. Ambulatory care sensitive conditions: general hospital of microregion of são paulo municipality, Brazil. Texto Contexto Enferm [Internet]. 2012 [acesso em 18 fev. 2016];21(3):535-42. Disponível em: http://www. scielo.br/scielo.php?script $=$ sci_arttext\&pid $=$ S010407072012000300007\&lng=en

20. Rodrigues-Bastos RM, Campos EMS, Ribeiro LC, Ribeiro LC, Firmino RUR, Bustamante-Teixeira MT. Hospitalizations for primary care-sensitive conditions in a Southern Brazilian municipality. Rev Assoc Med Bras [Internet]. 2013 [acesso em 01 fev. 2016];59(2):120-7. Disponível em: http://www. scielo.br/scielo.php?script=sci_arttext\&pid=S010442302013000200010\&lng=en

21. Serbim AK, Goncalves AVF, Paskulin LMG. Caracterização sociodemográfica, de saúde e apoio social de idosos usuários de um serviço de emergência. Rev Gaúch Enferm. 2013;34(1):55-63.

22. Reis RS, Coimbra LB, Silva AAM, Santos AM, Alves MTSSB, Lamy ZC, et al. Acesso e utilização dos serviços na Estratégia de Saúde da Família na perspectiva de gestores, profissionais e usuários. Cienc Saúde Coletiva. 2013;18(11):3321-31.

23. Marin MJS, Moracvick MYAD, Marchioli M. Access to health services: comparing the perspectives of professionals and users on primary care. Rev Enferm UERJ[Internet] 2014 [acesso em 08 mar. 2016];22(5):62936. Disponível em: www.e-publicacoes.uerj.br/index. php/enfermagemuerj/article/view/4238/12287

24. Levorato CD, Mello LM, Silva AS, Nunes AA. Fatores associados à procura por serviços de saúde numa perspectiva relacional de gênero. Cienc Saúde Coletiva. 2014;19(4):1263-74.

25. Gomide MFS, Pinto IC, Gomide DMP. Perfil de usuários em um serviço de pronto atendimento. Medicina. 2012;45(1):31-8.

26. Silva CSO, Fonseca ADG, Souza LPS, Siqueira LG, Belasco AGS, Barbosa DA. Integralidade e Atenção Primária à Saúde: avaliação sob a ótica dos usuários. Cienc Saúde Coletiva. 2014;19(11):4407-15.

27. Azevedo DSS, Tibães HBB, Alves AMT. Determinants of direct demand by the population with preventable situations. Rev Enferm UFPE. 2014;8(10):3306-13. 
28. Pires MRGM, Gottems LBD, Cupertino TV, Leite LS, Vale LR, Castro MA, et al. A utilização dos serviços de atenção básica e de urgência no SUS de Belo Horizonte: problema de saúde, procedimentos e escolha dos serviços. Saúde soc. 2013;22(1):211-22.

29. Silva SF. The organization of regional and integrated healthcare delivery systems: challenges facing Brazil's Unified Health System. Cienc Saúde Coletiva. 2011;16(6):2753-62.

Received: August 02, 2017

Reviewed: October 02, 2017

Accepted: November 08, 2017
30. Garcia VM, Reis RK. Adequação da demanda e perfil de morbidade atendida em uma unidade não hospitalar de urgência e emergência. Ciênc Cuid Saúde. 2014;13(4):665-73.

31. Lavras C. Atenção Primária à Saúde e a Organização de Redes Regionais de Atenção à Saúde no Brasil. Saúde Soc. 2011;20(4):867-74.

32. Ansari Z, Haider SI, Ansari H, Gooyer T, Sindall C. Patient characteristics associated with hospitalisations for ambulatory care sensitive conditions in Victoria, Australia. BMC Health Serv Res. 2012;12:1-24. 